\title{
CAS, its contribution to the development of civic competence
}

\author{
María Cañiza \\ Sara Ibarrola \\ Ángel Sobrino \\ Universidad de Navarra, España
}

\begin{abstract}
Nowadays, the world has made education rethink its goals and propose new horizons for students in the $21^{\text {st }}$ century. The violence observed in homes and streets, society, social problems, and inequalities have forced education to reconsider its moral function. It has also had to take a good look at affective education, the development of virtues and skills that contribute to a harmonious coexistence that aims for the common good and the construction of a peaceful world. Therefore, the acquisition of civic competence becomes a central topic to consider in current educational systems. The objective of this article is to identify the contribution made by the CAS (Creativity, Activity and Service) program to the development of civic competence. The evidence comes from a case study carried out in three Spanish educational centres that offer the International Baccalaureate Diploma Program. The sample indicated that the program has fostered the development of civic competence in students through a commitment to and participation in their communities and through interesting experiences and projects.
\end{abstract}

\section{Keywords}

Civic Competence, commitment, CAS, international baccalaureate.

Fecha de recepción: 13/II/2021

Fecha de aceptación: 24/III/2021

Cañiza, M.; Ibarrola, S. y Sobrino, A. (2021). CAS, its contribution to the development of civic competence. RIDAS, Revista Iberoamericana de Aprendizaje Servicio, 11, 45-63.

DOI 10.1344/RIDAS2021.11.3 


\section{CAS, y su contribución al desarrollo de la competencia ciudadana}

\section{Resumen}

En la actualidad, el escenario mundial pone de manifiesto la necesidad de 'repensar' la educación: replantear sus objetivos y establecer nuevos horizontes para los estudiantes del siglo XXI. La violencia observada en los hogares y en las calles, los problemas sociales y las desigualdades obligan a la educación a reconsiderar su función moral. Por otro lado, se hace necesario abordar la educación afectiva, el desarrollo de virtudes y las habilidades que contribuyan a una convivencia armónica que tenga como propósito el bien común y la construcción de un mundo pacífico. Por tanto, la adquisición de la competencia ciudadana se convierte en un tema central a considerar en los sistemas educativos actuales. El objetivo de este artículo es identificar la contribución del programa CAS (Creatividad, Actividad y Servicio) al desarrollo de la competencia ciudadana. La evidencia procede de un estudio de caso realizado en tres centros educativos españoles que ofrecen el Programa de Diploma del Bachillerato Internacional. La muestra indicó que el programa ha fomentado el desarrollo de la competencia ciudadana en los estudiantes a través del compromiso y la participación en sus comunidades y a través de interesantes experiencias y proyectos.

\section{Palabras clave}

Competencia cívica, compromiso, CAS, bachillerato internacional. 


\section{Introduction}

The growing interest in civism today has led to better comprehension and implementation in the classroom. The actual concern for civic education of students has forced educational systems to propone the acquisition of civic competence as an essential idea of curricula.

Participation in society is a moral duty for students, and it implies an active commitment to their community. Students need to be able to contribute to and improve their living environment, not only benefit from it.

First of all, this article introduces the concept of civic competence in a brief and concise manner. Although there is abundant literature on the matter, the concept is used in this research to aid the reader in recognizing the contribution of CAS to the development of civic competence. Secondly, the description and results of the methodology are revealed. Finally, the analysis of findings in the context of research literature is presented.

Civic competence is composed of knowledge, skills and attitudes that prepare individuals for community life, transforming them into active members. In other words, it makes human being competent for life in society (Bárcena Orbe, 1995).

CAS, a key subject in the International Baccalaureate and a core component of the Diploma Program, is taught in the two years of the baccalaureate. The acronym CAS stands for Creativity, Activity and Service. It aims to promote the individual and interpersonal development of students and to bring benefits to them, in aspects that other academic subject areas are not capable of reaching (Organización del Bachillerato Internacional, 2020a).

The program offers students the opportunity to be aware of their commitment as world citizens, allowing them to develop civic competence and become active and compassionate citizens, able to collaborate in the construction of more humane environments (Billig \& Good, 2013).

\section{Theoretical framework}

\subsection{Civic Competence}

Civic competence has become an important topic in the holistic formation of students, and therefore cannot be left out of educational programs and policies if the intention is to change and improve society. Parliament and European Council propose as the purpose of social and civic competences, the preparation of individuals for an increasingly complex and diverse social and professional life. Civic competence prepares everyone to participate in civic life through knowledge of structures and active commitment (Pagès, 2009).

In the first place, it is necessary to conceptualize citizenship, a term with assorted meanings. For this research, citizenship is the responsible exercise of duties and the enjoyment of rights. Therefore, an individual is a responsible and active citizen within society (Puig y 
Morales, 2015). The idea of an individual's commitment to the environment can also be added. A person sees himself as oriented towards others only when sharing (García del Dujo y Mínguez Vallejos, 2011). It is just through education that awareness of the construction of common good can be generated (Battistoni, 1997).

Appropriate education of civic competence is one that provides students with the knowledge, critical thinking skills and participation strategies, without neglecting values, interest for others' rights and searching for common good. Education is thus presented as an interesting proposal for the development of civic competence and the involvement of people in the life of society (Naval $y$ Arbués, 2008; Ugarte y Naval, 2010).

In this educational process, social competence or the possibility of adaptation to the environment appears as an important factor to consider when trying to educate civic competence. This adaptation to the environment does not mean going with the flow or behaving as others expect, but to learn to be reflective, autonomous and to take decisions according to personal and social well-being. In this sense, social competence is linked to civic competence because it needs civicmoral values to be adequate (López de Dicastillo et al., 2004). The importance of participation and the need to promote behavior that guarantees coexisting, without neglecting values and norms, are recognized. A different alternative to life is proposed, one in which values and norms are shared to respond with assertiveness to the demands and common responsibilities of life in society (Puig y Morales, 2015). It is clear that social competence is the basis of civic education. Its purpose is the achievement of civic and peacefully coexisting.

Civic competence comprises knowledge, skills, and attitudes. Its basis is social competence, therefore it must include:

- Knowledge about oneself, society and its norms, commitment and self-identification with the community, understanding of social structures and processes, comprehension of capacities and difficulties to interact in society.

- A moral status with values that involve attitudes such as respect, tolerance, sensitivity to the common good, openness to dialogue, trust in others, empathy, emotional control, solidarity, cooperation, acceptance of others and of cultural diversity, and management of social skills.

- Training on instrumental competencies and operational skills, such as the ability to solve conflicts, negotiation, decisionmaking, reflection, ability to put oneself in others' shoes, adequate communication, abilities to express and receive criticism (López de Dicastillo et al., 2008; Dam \& Volman, 2007).

Although the importance and approach to civic education have generated debate in certain contexts, its contribution is undeniable if one 
considers the need for an education that prepares students for life in society, for which some virtues and basic principles are needed such as the necessity of promoting active, committed citizenship, and the adoption of strategies that respond to the challenges of a society in constant change (Arbués et al., 2012).

The main concern is how to teach and practice civic competence. Santisteban (2009) boosted the proposal of exposing classrooms to real-world problems and generating connections with historical, geographical and social knowledge. Competence should be presented as a set of abilities that enables students to solve problems. Thus, it is necessary to develop critical and creative thinking, necessary skills for change and improvement. Students must be able to question the information they receive and see how it applies to immediate and global contexts. In addition, inquiry, dialogue, and teamwork should be encouraged.

Civic competence should be considered part of the curriculum and be addressed by all areas of knowledge and so acquiring a true meaning. In addition, this holistic approach should favor an education that develops skills and capacities useful for students' future lives, and to fundamentally contribute to and improve society.

Marina and Bernabeu (2007) mention that educational research agrees on the idea that schools can teach civic behavior and that civic participation can be promoted in classrooms. Schools have a great responsibility in connecting and involving students with their immediate environment, to make them aware of the reality of the global world. Therefore, the school is a privileged place to promote initiatives for service or volunteering projects in communities (Ugarte y Naval, 2010).

Research suggests that children develop social responsibility at the age of nine and it is important to address civics and citizenship for subsequent development of civic competence. Students in secondary education will be able to discover what they can do to improve society (Gibson \& Levine, 2003).

School becomes an ideal context to learn and develop civic competence. Education acquires the important role of promoting civic abilities and skills, which facilitates conscious-raising of duties, rights of others and identify the impact of a harmonious coexisting. School is a place where individuals can learn to live with others, in a world in need of social change. In addition, respect for differences and democratic coexisting is unavoidable (Puig y Morales, 2012; Subirats, 2014).

Naval et al. (2012) point out that civic education comprises the transmission of knowledge, and the acquisition of skills and attitudes. It is not only about knowledge, but about affections, emotions, qualities, and personal dispositions for achieving an active and responsible citizenship. Civic education does not remain a simple theoretical transmission of knowledge and theories that advocate a "duty to be", but it facilitates models and experiences that motivate students to get involved in concrete projects and actions. The CAS 
program is as an interesting proposal that contributes to the development of civic competence. So, besides the knowledge, students must be able to get involved and commit themselves to real environments. They learn to participate by taking part in activities that are truly committed to their communities.

\subsection{CAS program}

The CAS program reveals itself in this study as an interesting option to bring civic competence to the classroom offering students opportunities for interaction in real-world contexts.

CAS, a core component of the Diploma Program of the International

Baccalaureate, is a mandatory curricular subject in the holistic education of students. The three areas of CAS are (Organización del

Bachillerato Internacional, 2015):

- Creativity: exploration and expansion of ideas that lead to an original or interpretive product or performance.

- Activity: a physical effort that contributes to a healthy lifestyle.

- Service: collaborative and reciprocal commitment to the community in response to a true need (p.8).

CAS in a certain way "decompresses" the pressure of the other subjects of the Diploma Program. It offers student opportunities to develop and put into practice skills that are not only limited to academics but to sports, healthy living, art, music, painting, service to others and their community. The purpose of CAS is to enhance personal, interpersonal, and civic development of students through participation in service-learning activities (Billig \& Good, 2013).

It is important to highlight that servicelearning has been proven as an educational practice that allows the development of civic competence. The link between curricula and service leads to the development of civic virtues, as well as introducing some activities in the classroom: analyses of current events, debates on the problems and needs of the community and ways of solving them, and open dialogues about controversial issues of interest to the students (Gibson \& Levine, 2003; Kahne \& Sporte, 2008).

CAS seeks for students to learn, help others, develop an open mind, while emphasizing the service aspect. Not only because of the benefits it provides to the community, but also because the individual who serves or offers help is also enriched. It is as in a "dialectical relationship", in which both parties benefit, grow, develop and enjoy. The individual impacts his community, but the community also impacts the student's life (Kulundu \& Hayden, 2002).

The objectives of the CAS program are to develop students who:

1. Enjoy and find significance in a range of CAS experiences.

2. Explore new possibilities, embrace new challenges and 
adapt to new roles.

3. Purposefully reflect upon their experiences.

4. Actively participate in planned, sustained and collaborative CAS projects.

5. Identify goals, develop strategies and determine further actions for personal growth.

6. Understand they are members of local and global communities with responsibilities towards each other and the environment. (Organización del Bachillerato Internacional, 2015, p.10)

Goal number six implicitly shows that the civic formation of the students is one of its main aims. Recognizing that the students have responsibilities for others and to the environment is one of the goals of the program.

In the two years of high school, the students are expected to take on experiences, activities, and projects that involve challenges. Also, the development of a range of skills (even some unknown to them), and attitudes that lead to a commitment to their environment or community. These activities must generate motivation, enjoyment, and expectation in the students to be relevant. The frequency of activities could be weekly and the CAS project should last at least one month (Cannings et al., 2015).

The students should plan their experiences and projects following the stages described by Kaye (2010). These stages provide the students with a framework to work and a process to follow. First, they think about what they would like to do, then they plan, and finally, they materialize their ideas. The stages can be useful in other aspects of the student's life, for example when planning ideas for professional life, investigating a specific topic, reflecting as a means of improvement, modifying or generating new learning, or discovering new feelings and emotions. It also provides the students the confidence to undertake CAS experiences and projects.

CAS` stages (Kaye, 2010):

1. Investigation. This stage has two phases: a personal investigation and identification of community needs. Personal research is important for the students as it involves the discovery of interests, abilities, and talents.

2. Preparation and planning. At this stage, teachers and students work together to identify those skills to be acquired or improved to make them as effective as possible. Analysis, creativity, and proactivity lead students to develop an action plan with roles and responsibilities.

3. The action. After preparation and planning, the students apply what they learned to benefit the community. These actions should be valuable, meaningful, and significant to students. By taking action, students identify themselves as members of the community and learn how to 
work with social institutions. The action allows them to develop talents, abilities, and ideas to contribute to the common good.

4. Reflection. It is one of the pillars of CAS and a vital and continuous process that integrates learning and experience with personal growth and knowledge. Through reflection, they recognize how the experience, knowledge, and skills acquired impact their own lives and their communities. It is a pause that facilitates the exploration of the impact on learning and its effect on future thoughts and actions.

5. Demonstration. In this stage, the students make explicit what and how they have learned, and what they have achieved in the community. Presenting what they have learned allows the students to teach others, and at the same time identify and recognize their learning and how they have acquired it (a critical aspect of metacognitive development).

In this process, reflection is emphasized as a vital aspect because it gives meaning to what they have learned. It also generates learning that the students can transfer to their lives. Without reflections, CAS would be mere activism or a set of activities to fulfill the requirements of the program. "Reflection is fundamental for CAS students' experiences to be deep and valuable" (Organización del Bachillerato Internacional, 2015, p. 27). The students should notice that those reflections are an important part of their personal growth and that they will mark their lives.

The students need to comprehend that reflection is inherent to the whole process and development of the program. Reflection is not a product of experiences because it is present at the preparation and planning of every experience until the moment it is evaluated. Reflection enables the students to rethink their actions, project ideas, and improve them.

\subsection{Impact of CAS}

The research based on the CAS program and its implementation have provided clear evidence of the contributions and impact of CAS on the students.

Among the benefits, we find the development of talents and abilities unknown to the students, the possibility of interacting with others, the recognition of other perspectives putting themselves in the place of others, and the commitment to the environment to improve it. The different activities in the CAS program have taken the students out of their comfort zone, interacting with others, getting benefits, and benefiting those receiving the service or experience. Without CAS, many students would not have participated in such activities. Through participation, they uncover their potential and the real help they can provide, how useful they can be for society, and how much they can grow as a result of the experiences (Hayden et al., 2017). 
Another study has revealed that the service aspect of CAS is one that has impacted students the most. It has helped students get out of the "bubbles" where they had lived and become the subject where they learned the most, felt best and developed greater commitment (Lindemann, 2012). The CAS service component is another aspect in which the International Baccalaureate attempts to approach civic objectives described in the student's profile. This profile is made up of a list of attributes, which include capacities, abilities, and skills that are expected of students upon completing the International Baccalaureate Diploma Program (Organización del Bachillerato Internacional, 2020b). The purpose of Service is to make the students contribute to society and to identify their responsibilities as members of a community (Saavedra, 2016).

Service or volunteering activities normally linked to the school curriculum promote the development of civic competence much more than those carried out in isolation or as a result of personal interests (Gibson \& Levine, 2003).

The experiences lived by the students in CAS have left significant impressions on them. They are constantly searching for different ways to give continuity to what they started, be it volunteering activities, or creativity, such as writing (Thoilliez and Rappoport, 2018).

CAS activities have shown an impact on the construction of citizenship. The community recognized the useful contribution of the students and the impact of CAS activities to society. These activities have also favored the students' possibilities of discovering new realities, different from their own, awaking their consciousness and solidarity, and strengthening civic values over time (Pérez Pérez, 2015). "The activities the students carry out in the program reveal interest in their community and a sense of belonging to the nation, besides thinking about others" (Pérez Pérez, 2015, p.46).

A certain degree of a critical approach to global citizenship within the CAS program has been perceived. In the process of project planning, real causes of social problems are analyzed. The contribution of CAS to global citizenship education is undeniable (Carvalho, 2018).

International Baccalaureate students perceive themselves as more civicminded thanks to the CAS program. They also attribute the development of leadership skills and positive civic attitudes to CAS (Billig, 2017).

The mission of the International Baccalaureate states the idea that a good citizen is one who is actively involved in the improvement of society. The IB Learner Profile consists of ten attributes students are expected to develop related to the characteristics that define a 'good citizen'. Why? Because a good citizen should know how and why to be a committed citizen. A good citizen must think critically, analyze news, solve problems, propose improvements, work with others, and know how to disagree and acknowledge other ideas and perspectives. They must communicate effectively in order 
to share ideas, defend rights, and develop responsibility and commitment. This suggests that the development of civic competence is one of the main goals of the International

Baccalaureate. Guidelines of different courses and subjects do not explicitly detail the development of citizenship on the students, but they refer to the development of civic competence using a 'suggestive' language (Saavedra and Opfer, 2012; Saavedra, 2016).

The students can develop many important skills for civic engagement through CAS but this depends on how each center organizes the program, and the level of motivation of the students (Saavedra, 2016).

Thanks to CAS, the students developed a greater awareness of existing social problems. One of the main reasons the students chose an activity for CAS was to learn about others, their own reality, and to help others (Lindemann, 2012).

CAS complements the academic education of the International Baccalaureate and contributes to the holistic formation of the students, empowering them with qualities that will transform some of them into agents of change. To achieve this, not only knowledge is needed but values, ethics, and empathy to collaborate in the construction of a better world.

\section{Methodology}

This article is based on part of the fieldwork of qualitative research on a case study of the CAS programs in three Spanish educational centers. The findings of the contribution of the CAS program to the development of civic competence are presented.

The case study is a research method whose major characteristic is the inquiry through an example (Álvarez Álvarez y San Fabián Maroto, 2012). Colás Bravo (1998) has characterized the case study as an investigation of issues that are known particularly through study cases, complex or simple, such as an educational center, a student, or a class. The case study has allowed us to research the CAS program in its natural context (Yin, 2003).

This research method is based on a collective case study. Three centers have been selected to make an interpretation of the CAS program (Stake, 1998). The general inductive approach has been used to analyze the collected data. This has led the results to emerge from frequent or significant issues related to raw data (Thomas, 2006).

The information-gathering was conducted in three Spanish educational centers. Each center received a presentation of the study and provided a letter of consent. The visits to each center were scheduled and implemented from January to June 2019.

Data was collected through questionnaires and discussion groups (see table 1).

The Likert scale with closed questionnaires and affirmative statements was used. The students could add comments for some 
questions, and provide justification or opinions for others. The questionnaires were sent to the eighty-eight students of the diploma program at the three centers. Seventy-nine students responded.

The discussion groups were moderated by the researcher using prepared questions. The groups of a minimum of four and a maximum of eight students were randomly formed by the coordinators of each center. All students of the diploma program at the three centers took part of the discussion groups (eighty-eight students).

Table 1. Instruments and participants

\begin{tabular}{cc}
\hline Instruments & $\begin{array}{c}\text { Number of } \\
\text { participants }\end{array}$ \\
\hline Questionnaires & 79 students \\
Discussion Groups & 88 students \\
\hline
\end{tabular}

Source: own elaboration

Before the administration of instruments, an informed consent from each student was requested. The Ethics Committee of the University of Navarra reviewed and approved the instruments.

Once the information was collected, the qualitative data were processed, and the inductive content analysis was performed. All the information collected from the informants has been duly encrypted, safeguarding their anonymity and confidentiality. Analysis categories were established from the data of the collected information for its interpretation and subsequent presentation.

\section{Results}

The analysis of the data from the questionnaires and discussion groups has generated the following results grouped into categories.

\subsection{The "Service" aspect}

As mentioned before, of the three areas of CAS, Service has been the one that generated the most impact on the lives of students. Through service, students learned to develop commitment, discovered how positive it was to dedicate hours of their lives to serve, identified different social realities, and took part in social projects. All these allowed students to get out of their comfort zone and interact with others. Without CAS, they might not have been involved in this type of experience, nor would they have discovered how useful they could be for society. The service within CAS is significant because of the benefits it offers not only to the student but to the community that receives the service (Billig \& Good, 2013; Billig, 2017; Hayden et al., 2017; Kulundu \& Hayden, 2002; Lindemann, 2012).

Both research literature and findings of this study reveal the importance of Service within CAS, its high and positive impact, and its contribution to the development of civic competence. Service has favored the development of social awareness and the notion of reality, active citizen engagement, critical reflection, empathy, decisionmaking, and the importance and consequences of civic participation, all of which are key components of civic 
and social competences:

- " [...] Service experiences allow the development of citizenship commitment and empathy" (CGD, CEA, PC, P. 6a).

Other competences, aptitudes, and skills that developed through service experiences have also been cited such as empathy, reflexive capacity, criticism, and decision-making:

- "[...] The reflexive capacity and to empathize with others are what leads me to feel a citizenship commitment to my neighbors, [...] the ecology, and the place in which I live $[\ldots]^{\prime \prime}$ (CGD, CEA, SC, P. 6a).

- "[...] A complete citizenship commitment includes being able to empathize with others, to critically reflect on the realities that surround us, to make decisions about it [...]" (CGD, CEA, SC, P. 6a).

In the discussion groups, the students commented on the enriching experiences lived through Service, highlighting their learning, and what they will take throughout their lives:

- "[...] I think that the CAS service component is the one that perhaps makes the most difference and the one that makes you grow the most as a person and the one that you will remember the most as something that truly made you change $[\ldots]^{\prime \prime}$ (FG3, CEB, P.10, EV1.1).

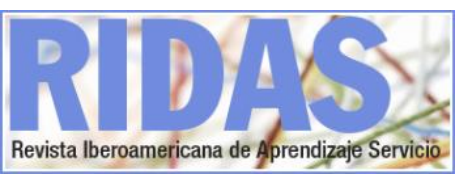

- "[...] Service is [...] (what) [...] has contributed the most to me. [...] Activity and Creativity [...] are easier to do, [...] but Service [...] is the one that has given me the most because I have learned a lot [...]. It has made me see life through different eyes because you live experiences that if it were not for CAS I would not have lived $[\ldots]$ " (FG6, CEB, P.10, EM1.1).

A student stated the contribution of CAS:

- "[...] At the end, in five years, I will not remember the final exam in Biology [...], I will remember the time we all went to plant trees [...] and the volunteering that I did $[. .$.$] , those are the$ experiences that I take from the diploma and [...] it is what has impacted me the most. I think that during these two years we have changed and matured a lot and not [...] because we have done 20 chapters of Mathematics, or because we have read six books but because we have been exposed to situations to which we were not used to. [...] CAS has been very important, the service component because [...] I have always been a person who has played sports or I have always been involved in some way in creative extracurricular activities, music or sports, but nevertheless the service part had never occurred to me [...]. The service activities have helped me realize the reality other people live [...] if 
they had not made me do it, I would not have done them [...]" (FG3, CEB, P.5, EM1 .1).

Recognizing the satisfaction generated by helping others and at the same time, identifying contribution and usefulness within society is important in the process of developing civic awareness:

- "[...] It is easier for a volunteering activity to impact you (...) I think that everyone feels good when they help another person with their abilities (...). At the end you see that you are helping someone. That impacted me a lot [...]" (FG4, CEB, P.10, EM1.2).

\subsection{The CAS program and civic Competence}

CAS is a program that allows students development in personal and interpersonal aspects. The involvement in different and varied activities has enabled students to discover, develop, and enhance talents and important virtues for their growth as individuals, and in interaction with others. In this coexisting with the "other", the students have managed to discover the contribution they, as citizens, can offer to society.

Thanks to CAS, they have developed citizenship commitment:

- "[...] I consider that the CAS program has developed in me an attitude of citizenship commitment, of commitment to society, doing some service for others" (CGD, CEC, 6a).

Other students noted that thanks to CAS they discovered the contribution they can make to society, since the program is not solely oriented to the academic field, like other subjects:

- "I think that civic engagement is something that, otherwise, is difficult to learn in school - which is very oriented to the academic field [...]" (CGD, CEA, SC, P. 6a).

- " [...] Citizenship commitment is something that I did not have before learning about this subject and once you are involved you realize the real value you have in society" (CGD, CEB, 6a).

- "[...] I have done things that I wouldn't have done before, things that made me feel better. After these experiences, a stronger sense of citizenship has aroused in me" (CGD, CEB, 6a).

Other important contributions of CAS are the discovery of reality but not from the unique perspective they used to have, the consequent motivation to "get out of the comfort zone", the embarking on new and challenging projects, and the improvement of social awareness:

- "[...] It opens you up to reality, because you see many perspectives of realities in the daily lives of many people [...]. At first you only have one perspective on life, but CAS opens you up to[...] other 
perspectives by volunteering $[\ldots]^{\prime \prime}$ (FG2, CEA, P.10, CS1E11).

- "[...] CAS [...] has made me leave my comfort zone and [...] see things that I would not have seen otherwise [...]. That has led me to see [...] the capacities we have and to put them at the service of others, to be more self-critical, to have more commitment, to see what I do for others [...]" (FG3, CEA, P.8-9, CS2E3).

- " "...] It has opened my mind a lot. I am not only in my world [...] (but) there are people who are having a hard time and [...] who are not as lucky as you [...]" (FG1, CEC, P.5, AM1.2).

Everything mentioned by the students is key to the development of civic competence, knowing and valuing other perspectives, discovering other realities that coexist in the community, recognizing talents and putting them at the service of others, developing selfcriticism and commitment.

As mentioned before, social competence is linked to civic competence because it needs civicmoral values to be adequate (López de Dicastillo et al., 2004). Therefore, the values acquired through CAS constitute as a key contribution:

- "[...] What I have absorbed the most from CAS are those values that form you as a person [...]. I trained some young boys in soccer school and helped them establish certain values on and off the field that will make them grow as persons [...]: respect [...], camaraderie, being a team [...]. It is what truly makes you learn [...] and I believe that these values are the most important things about CAS" (FG3, CEB, P.10, EV1.2).

The following transcription summarizes the findings of this research. CAS favors the development of civic competence, commitment, and social responsibility. The various experiences that students had to embark on to approve this core component of the Diploma Program have fostered their personal growth and the development of greater civic awareness. All of these have allowed them to get involved in society and contribute to the construction of dignified places for everyone.

One student summarizes it:

- "[...] CAS [...] is the being a good person subject (...) it is for life really [...] it shapes you as a person $[. .$.$] in terms of the values$ that we carry. A certain discipline because we do many activities [...] in which you have to commit yourself (...) for months or a whole year or two [...]. I feel fortunate to have a subject that is not so "academic" because many times we think that we are in school only to learn Mathematics, Biology [...] but [...] I think it is important that they train us as citizens, as people who are going to go out to the world $[. .$.$] "(FG3, CEB, P.10,$ EM1.3). competence. RIDAS, Revista Iberoamericana de Aprendizaje Servicio, 11, 45-63. 


\section{Conclusions}

In the three educational centers under study, civic competence is one of the most developed and enhanced competence in the CAS program. The significant link between social and civic competence, should also be noted. CAS allowed students to become aware of reality, take part and get involved in, and develop commitment and social responsibility, which has favored their training as citizens of the world. Undertaking extra activities and venturing out to do things that if not for CAS they would not have done has led to extremely positive and satisfactory results, all recognized by the students in the study.

"Service" is the aspect of CAS that has impacted all students the most in the three centers and it is precisely where they can adequately develop civic competence. They found themselves immersed in the actual world, assuming real roles, taking responsibility, and committing to their own environment. They have also mentioned that the experiences of Service have left lasting marks and motivated them to change. They said they even began "to see life through other crystals" and were able to contribute a bit more to improve society.

Based on the work conducted in this study and the data collected from the students, some recommendations emerged that could help centers with the CAS program. On one hand, there should be a link between the subjects of the Diploma Program and the CAS component. So the activities students undertake acquire greater significance, meaning and relevance, so as not to be perceived just as a mandatory component to approve the Diploma. On the other hand, to promote spaces for debate and sharing experiences planned and lived at school. For example, during CAS hours, the advisor/coordinator could generate discussion groups about the experiences, progress of the projects, reflections, and learning. This way, they will be able to establish criteria for improvement that will lead to experience a more effective and meaningful CAS experience.

This work is based on a case study of three Spanish educational centers. It is not a sample to establish generalizations, but it could be used for subsequent lines of research on the development of civic competence in educational centers. There are other methodologies, such as service-learning that, through research, have shown its contribution to the development of students' civic competence. Links can be established between CAS, servicelearning, and other programs that help develop this competence necessary for life in society, and for the construction of the collective good.

\section{References}

Álvarez Álvarez, C. y San Fabián Maroto, J. L. (2012). La elección de estudio de caso en investigación educativa. Gazeta de Antropología, 28(1), 1-13. Retrieved from https://repositorio.unican.es/xmlui/han dle/10902/4162

Arbués, E., Naval, C., Reparaz, Ch., Sádaba, Ch. y Ugarte, C. (2012). La 
competencia social y cívica. Guía didáctica. Parlamento de Navarra Servicio de publicaciones Universidad de Navarra. Recuperado de https://dadun.unav.edu/bitstream/1017 1/23100/1/Gu\%c3\%ada\%20did\%c3\%a 1ctica-pdf-online.pdf

Bárcena Orbe, F. J. (1995). La educación moral de la ciudadanía. Una filosofía de la educación cívica . Revista de educación, (307), 275-308. .

Retrieved from

https://redined.mecd.gob.es/xmlui/han dle/11162/70524

Battistoni, R. (1997). Service learning and democratic citizenship. Theory Into Practice, 36(3), 150-157. Retrieved from

https://digitalcommons.unomaha.edu/s Iceslgen/86/

Billig, S. \& Good, B. (2013).

International Baccalaureate Diploma Programme: Study of North and South American Students' Civic-Mindedness. Retrieved from https://www.ibo.org/research/outcome s-research/diplomastudies/international-baccalaureatediploma-programme-study-of-northand-south-american-students-civicmindedness-2013/

Billig, S. (2017). Service and ServiceLearning in International Baccalaureate High Schools: An International Comparison of Outcomes and Moderators. The International Journal of Research on Service-Learning and Community Engagement, 5(1), 57-83. Retrieved from https://journals.sfu.ca/iarslce/index.ph p/journal/article/view/197
Cannings, J., Piaggio, M.I., Muir, P. \& Brodie, T. (2015). Creativity, Activity, Service (CAS). Cambridge, United Kingdom: Cambridge University Press.

Carvalho M. E. (2018). Going Global in Costa Rica: A Mixed Method Study Examining Teachers of the International Baccalaureate Diploma Program and Its Growth in a Developing Country (Doctoral thesis). Florida Atlantic University, Florida, USA. Retrieved from http://fau.digital.flvc.org/islandora/obje ct/fau\%3A40785

Colás Bravo, P. (1998). Métodos y Técnicas cualitativas de investigación en Psicopedagogía. In L. Buendía, P. Colás Bravo and F. Hernández, Métodos de investigación en psicopedagogía (pp. 251-286). Madrid, España: McGrawHill.

Dam, G. \& Volman, M. (2007). Educating for Adulthood or for Citizenship: Social Competence as an Educational Goal. European Journal of Education, 42(2), 281-298.

García del Dujo, Á. y Mínguez Vallejos, R. (2011). Los límites de la educación en valores cívicos: cuestiones y propuestas pedagógicas. Educación $X X 1,14(2), 263-284$. Retrieved from http://revistas.uned.es/index.php/educ acionXX1/article/view/254/209

Gibson, C. \& Levine, P. (2003). The civic mission of schools. CIRCLE and Carnegie Corporation of New York Retrieved from https://media.carnegie.org/filer public/ 9d/0a/9d0af9f4-06af-4cc6-ae7d71 a2ae2b93d7/ccny report 2003 civic mission.pdf 
Hayden, M., Hemmens, A., McIntosh, S., Sandoval-Hernández, A. \& Thompson, J. (2017). The impact of creativity, action, service (CAS) on students and communities. Retrieved from https://www.ibo.org/globalassets/public ations/ib-research/dp/cas-finalreport2017-en.pdf

Kahne, J. \& Sporte, S. (2008).

Developing citizens: The impact of civic learning opportunities on students' commitment to civic participation. American Educational Research Journal, 45(3), 738-766. Retrieved from https://www.researchgate.net/publicati on/240611047 Developing Citizens Th e Impact of Civic Learning Opportuni ties on Students\%27 Commitment to Civic Participation

Kaye, C. B. (2010). The Complete guide to service learning: proven, practical ways to engage students in civic responsibility, academic curriculum, \& social action. Free Spirit Publishing Inc.

Kulundu, F. \& Hayden, M. C. (2002). Creativity, Action, Service (CAS) Activities as Part of the International Baccalaureate Diploma Programme: A Case Study. Pastoral Care in Education, 20(1), 30-36 doi: 10.1111/14680122.00218

Lindemann, I. (2012). Perceptions of former International Baccalaureate Diploma Programme (IBDP) students on the transformational impact of the Service element of Creativity Action Service (CAS) on their lives: a case study from Brazil (Doctoral thesis). University of Bath, Bath, England. Retrieved from
http://ethos.bl.uk/OrderDetails.do?uin= uk.bl.ethos.600643

López de Dicastillo, N., Iriarte, C. y González, M. (2004). Aproximación y revisión del concepto "competencia social". Revista española de pedagogía, 62(227), 143-156. Retrieved from https://dialnet.unirioja.es/servlet/articu lo?codigo $=866882$

López de Dicastillo, N., Iriarte, C. y González, M. (2008). Competencia social y educación cívica. Madrid, España: Síntesis.

Marina, J.A. y Bernabeu, R. (2007). Competencia social y ciudadana. Madrid, España: Alianza Editorial.

Naval, C. y Arbués, E. (2008). ¿Ciudadanos de manual? Nuestro tiempo, (645), 25-35. Retrieved from https://dadun.unav.edu/handle/10171/ $\underline{20709}$

Naval, C., Arbués, E. y Repáraz, Ch. (2012). Sobre la enseñanza de la competencia cívica. In F. Gil Cantero y D. Reyero García (Coords.), Libro Homenaje al profesor José Antonio Ibáñez-Martín Mellado (pp. 224-239). Madrid, Esoapa: Biblioteca Online. Retrieved from http://hdl.handle.net/10171/36653

Organización del Bachillerato Internacional. (2015). Programa del Diploma. Guía de Creatividad, Actividad y Servicio. Retrieved from http://www.educa.madrid.org/web/ies.r amirodemaeztu.madrid/bi/guia cas 20 17.pdf 
Organización del Bachillerato Internacional. (18 de noviembre de 2020a). Creatividad, Actividad y Servicio (CAS). Retrieved from https://ibo.org/es/programmes/diploma -programme/curriculum/creativityactivity-and-service-projects/

Organización del Bachillerato Internacional. (24 de noviembre de 2020b). El perfil de la comunidad de aprendizaje del IB. Retrieved from https://www.ibo.org/es/benefits-of-theib/the-ib-learner-profile/

Pagès, J. (2009). Competencia social y ciudadana. Aula de innovación educativa, (187), 7-11. Retrieved from https://ddd.uab.cat/record/182046

Pérez Pérez, B.H. (2015). Construcción de la ciudadanía: Una aproximación desde las Constituciones (1863 - 1886 - 1991) y su articulación con el componente CAS en los colegios IB de Bogotá (Master's thesis). Universidad Militar Nueva Granada, Bogotá, Colombia. Retrieved from https://repository.unimilitar.edu.co/bitst ream/handle/10654/6780/PerezPerezBe atrizHelena2015.pdf; jsessionid=F4FB86 C7AA60FC7332FF6A85A8537660?seque $\underline{\text { nce }=1}$

Puig, J. M. y Morales, J.A. (2012). La competencia social y cívica: una aproximación a la realidad escolar. Revista española de pedagogía, (253), 441-460. Retrieved from https://ezproxy.si.unav.es:3293/eds/pd fviewer/pdfviewer?vid =2\&sid $=073 a 18$ a 8-e97d-4698-9c57aabe0300a54c\%40sessionmgr4006
Puig, J. M. y Morales, J. A. (2015). La formación de ciudadanos: conceptualización y desarrollo de la competencia social y cívica. Educación $X X 1,18(1), 259-282$. Retrieved from http://revistas.uned.es/index.php/educ acionXX1/article/view/12332/12222

Saavedra, A. (2016). Academic Civic Mindedness and Model Citizenship in the International Baccalaureate Diploma Programme. Social Studies, 107(1), 1-13. doi:

10.1080/00377996.2015.1094722

Saavedra, A. \& Opfer, V. (2012) Teaching and Learning 21st Century Skills: Lessons from the Learning Sciences. The Asia Society. Retrieved from http://asiasociety.org/files/rand1012report.pdf

Santisteban, A. (2009). Cómo trabajar en clase la competencia social y ciudadana. Aula de innovación educativa, (189), 12-15. Retrieved from https://ddd.uab.cat/record/182049

Stake, R. (1998). Investigación con estudio de casos. Madrid, España: Morata.

Subirats, M. (2014). La LOMCE: Hacia una educación antidemocrática. Revista interuniversitaria de Formación del Profesorado, (81), 45-58. Retrieved from

https://dialnet.unirioja.es/descarga/arti culo/5009038.pdf

Thoilliez, B. y Rappoport, S. (2018). El Programa del Diploma de Bachillerato Internacional en institutos públicos españoles: tres miradas sobres las voces de sus antiguos alumnos. Journal 
of Supranational Policies of Education,

(7), 83-104. Retrieved from

https://repositorio.uam.es/handle/1048

6/684369 Thomas, D. (2006). A

General Inductive Approach for

Analyzing Qualitative Evaluation Data.

American Journal of Evaluation, 27(2),

237-246.

doi: $10.1177 / 1098214005283748$

Ugarte, C. y Naval, C. (2010). La

formación política de los alumnos de

educación secundaria. Descripción y

valoración de programas de Service-

learning en los Estados Unidos y la

Unión Europea. Edetania: estudios y

propuestas socio-educativas, (37), 109-

128. Retrieved from

https://dadun.unav.edu/handle/10171/

$\underline{21593}$

Yin, R. (2003). Case study research:

Design and methods. London, UK:

Thousand Oaks Sage. 